\title{
Financial Performance Analysis of PT PLN Java-Bali Power 2 (PJB2) In Order Execution Go Public
}

\author{
Aminullah Assagaf \\ Department of Master Management, Post Graduate Program, University Dr. Sutomo Surabaya, \\ East Java, Indonesia
}

\begin{abstract}
The purpose of research is the study of financial indicators to ensure the success of PT PLN PJB2 go public, and identify the factors that influence financial performance. Besides, it presents an alternative wisdom to improve the financial performance of PT PLN PJB2.

The data used are time series data to study the function of electricity demand Java-Bali system, while the analysis of the financial performance using financial statement data from 1995 to 1997 and the action plan of the data companies (CBP) in 1998.

The results showed that: The financial performance is quite healthy in terms of liquidity and solvency. But in terms of collection of accounts receivable activity showed stunted terms of profitability shows that the financial performance of PT PLN PJB2 relatively very low compared to other companies that have successfully gone public. PJB2 PT PLN's financial performance in 1996 and 1997 show a return on equity (ROE) $5.71 \%$ and $2.29 \%$, while return on assets (ROA) $4.78 \%$ and $1.85 \%$. In comparison PT Indosat financial performance in 1997 showed $20.36 \%$ ROE and ROA 18.31\%. While the cost structure of PT PLN PJB2 shows that contribution margin is still positive, which means that any market share gains led to increase profits and demand projections indicate that up to 2003 PT PLN PJB2 will grow quite rapidly.
\end{abstract}

Keywords: Financial Performance, Power Java Bali, Order Execution, Go Public.

\section{Introduction.}

PT PLN PJB2 that are objects of research studies have generating units, namely Generation Unit Gresik, Brantas Generation Unit, Power Unit Paiton Cirata Power Unit, Power Unit 2 Muara karang and business units . and in the study of widely used econometric models, as well as some results of studies that have been obtained, it forecasts electricity demand is influenced by several factors or independent variables . Several independent variables used in the study tend to be similar, and different is dependent on the specifics of his research .

Asia Pacific Institute for Management Development put forward the concept of evaluating the company's performance in the competitive situation. Of the concept is emphasized that the financial statements and the balance sheets and profit and loss budget analysis company, the company's financial performance can be measured via the method of comparison or ratios based on financial data available .

Amarullah (1984) use an econometric approach with non- linear models, using the data time series 1970 to 1979 the electricity demand of households in Indonesia, with the result : Ln Y $=-1.096-0.393 \mathrm{Ln}$ Y / $\mathrm{N}-0.484$ Ln XPR + 0.910 Ln EXP

where Y demand for electric power sector in Indonesian households, Y / N income per capita, XPR average price per $\mathrm{kWh}$ and EXP residents who have power .

Zuhal (1985) use an econometric model of non- linear approach ( 1n ) based on time series data in 1974 and 1980 the demand for electricity the household sector, the commercial sector and the government sector in Java ( RCELWJT ) with the result : RCELWJT Ln $=-20+0.72022$ Ln HHEX

Where HHEX is household consumption expenditure. In the industrial sector, manufacturing Java using gross domestic product ( MFIO ) as independent variables that affect the demand for electricity with the result : INELWJT Ln $=-1925.8+3.9473$ Ln MFIO PLN electricity demand study area VIII South Sulawesi Tenggara by Aminullah A (1994) using non-linear models with cross section data and time series of data on the household sector, the business sector, industrial sector and hospitality sector. The variables used were electricity rates, population growth, the installed power of consumers, income per capita and the proportion of the overall cost of electricity costs incurred concerned consumers .

study of the electricity demand in the United States by Thomson, WF (1976 ) forecast electricity demand based on data time series 1964 to 1974 with non- linear regression models . The independent variables used are the growth of gross national product ( GNP) for 1975 projected demand up to the year 2000 . Demand scenarios presented in the study are high growth, moderate growth and low growth .

Bangladesh's power demand studies by Russell and Richard (1982 ) using a time series of data to project the demand for Bangladesh's power until 1994. The independent variables used in the model are 
economic growth and changes in the level of production of each sector such as agriculture, industry, transport sector, domestic sector, trade and service sectors .

Study of electricity demand by Brazil Cascavel City Munasinghe, M ( 1979 ) using a time series of data with non- linear models. The independent variables used to project earnings power demand of household sector, industrial sector, the business sector, the government sector and the social sector .

\section{Methods.}

Based on several studies will be electricity demand both domestically and in several other countries , so in this study used three independent variables to project the demand for Java-Bali power system , the installed power consumers ( X1 Power ), gross regional domestic product ( X2PDRB) and development population ( X3PDDK ). The data used are time series in 1980 and 1996 with non- linear models as follows :

YKWHi Ln = Ln Ln X1 Power B0 + B1 + B2 + B3 XPDRBi Ln + Ln X3PDDKi Ui

Where YKWHi Java-Bali electricity demand in the observations to and is the observation error variable to . The estimation results are used for forecasting electricity demand Java Bali, is then used to calculate the share of energy demand that will be included in the financial projections of PT PLN PJB2 . Estimation results according to the data .

The data used in the study are derived from secondary data in accordance with the reported financial information periodically and financial projections for the medium and long term . Utilization statistics PLN Java-Bali in particular to gain an overview of the potential demand and the possibility of growth in the future .

The method used for the analysis of financial performance problem solving PT PLN PJB2, namely: financial ratio analysis to go public as follows : 1 . Liquidity Ratios, 2 . Activity ratio, 3 . Solvency ratio (Leverage ), 4 . Profitability ratios ( profitability ).

While the approach of structural analysis in terms of cost and tariff structure projected demand faced by PT PLN PJB2 . were used, namely: Analysis of the cost structure that reflects the variable costs and fixed costs in relation to determination of the transfer pricing used in this case contribution margin analysis and breakeven analysis or break-even point .

a. Analysis contribution margin ( CM ) or variable costing, b. Analysis regression, is used to measure the influence of independent variables on the demand for electric power .

Exchange rate selected in the determination of the research is at a reasonable level and according to the variations that have occurred since made the action plan of the company ( CBP ) PT PLN PJB2 until March 1998 , to select the interval between $\$ 1=$ USD $\$ 3200$ up to $\$ 1=\operatorname{Rp} 10,000$.

ROE is selected in the sensitivity analysis is the variation between $15 \%$ and $20 \%$, while ROA been between $10 \%$ and $15 \%$ as company experience who have successfully gone public as PT Telkom and PT Indosat . Electricity sales tariff or transfer pricing from the scenario depicted is the break even point conditions, specific ROE and ROA at various dollar exchange rate ( USD ).

\section{Analysis Of Financial Performance Pt PIn Java Bali Electricity Generation 2 (Pjb2).}

\section{Financial Ratio Analysis}

In a comparative analysis will be shown in two consecutive periods, namely 1996 and 1997 . Financial statement data are used for 1996 based on audited by Public Accountant Drs. Hadi Sutanto \& Partners, while the 1997 data before the audit.

\section{Liquidity levels}

This ratio is intended to assess the company's ability to pay short-term debt at maturity by using current assets available.

(a) Current ratio is obtained by comparing current assets to current liabilities current assets

Current Ratio $=$ current liabilities

$$
\begin{aligned}
- \text { Year } 1996 & =\frac{684.114 .358}{261.853 .165} \times 100 \%=261,26 \% \\
- \text { Year } 1997 & =\quad \frac{839.150 .691}{455.218 .154} \times 100 \%=184,34 \%
\end{aligned}
$$

Ability to pay short-term debt of PT PLN PJB2 declined in 1997, but still within reasonable limits or liquid enough as it is still above $100 \%$.

Quick ratio or acid test ratio, which does not take into account in assessing the inventory with the inventory comparison:

current assets-inventory

Quick ratio = - current liabilities 


$$
\begin{aligned}
- \text { Year } 1996= & \frac{684.114 .358-64.760 .695}{261.853 .165} \times 100 \%=236,53 \% \\
- \text { Year } 1997= & \frac{839.150 .691-107.001 .414}{455.218 .154} \times 100 \%=160,83 \%
\end{aligned}
$$

Though not take into account the inventory, but PT PLN PJB2 still quite liquid or above $100 \%$. Cash ratio, liquidity is assessed only by taking into account the company's cash by comparison: cash

Cash Ratio

$$
\text { current liabilities }
$$

$$
\begin{aligned}
\text { - Year } 1996= & \frac{86.035 .445}{261.853 .165} \times 100 \%=32,86 \% \\
\text { - Year } 1997= & \frac{98.647 .943}{455.218 .154} \times 100 \%=21,67 \%
\end{aligned}
$$

PT PLN PJB2 have cash ratio is relatively small, but the level of liquidity do not need to worry if supported with good cash flow plan.

\section{Activity level}

Asset turnover, measures the ability of the company increased sales turnover as well as to accelerate the return of assets.

$$
\begin{aligned}
& \text { annual sales } \\
& \text { Asset turn over =---------------------- } \\
& \text { - Year1996 }=\frac{2 \cdot 030.215 .036}{(6.204 .181 .875-6.052 .654 .733) / 2}=0,33 \mathrm{kali} \\
& \text { - Year } 1997=\frac{2.051 .688 .380}{(6.194 .727 .201-6.204 .181 .875) / 2}=0,33 \mathrm{kali}
\end{aligned}
$$

An increase in sales of $1.06 \%$, but due to the addition of assets that is proportional to the increase in sales, so the turnover rate remains 0.33 times or it will take about 3 years to reach the same once the turnaround or sale of assets. It seems that PT PLN PJB2 1997 still experiencing difficulties in increasing sales turnover, although the potential generating capacity is still sufficient demand to absorb greater amounts. Capacity factor until the end of 1997 , only around $60 \%$.

$$
\begin{aligned}
& \text { Account receivable turn over }=\text { annual credit sales } \\
& \text { accounts receivable (average) } \\
& - \text { Year } 1996=\frac{2.050 .215 .036}{(515.547 .792+31.400 .818) / 2}=7,42 \mathrm{kali} \\
& \quad-\text { Year } 1997=\frac{2.051 .688 .380}{(575.478 .100+515.547 .792) / 2}=3,76 \mathrm{kali}
\end{aligned}
$$

Accounts receivable collection performance in 1997 decreased, this happens because the PT PLN PJB2 not received payment of receivables from PT PLN (Persero). Average age of accounts receivable, accounts receivable reflects the billing period in one year.

$$
\begin{aligned}
& \text { Average of account receivable }=-\begin{array}{c}
\text { average }(\text { receivables }) \\
\text { The median sales }
\end{array} \\
& \text { Year } 1996=\frac{(515.547 .792+31.400 .818) / 2}{2.030 .215 .036} \times 365=49,17 \text { day }=(50 \text { day }) \\
& \text { Year } 1997=\frac{(575.478 .100+515.547 .792) / 2}{2.051 .688 .380} \times 365=97,05 \text { day }=(98 \text { day }) .
\end{aligned}
$$

1997 billing period increased from 50 days to 98 days, resulting in the deposition of about 3 months sales of funds that have not been transferred from PT PLN (Persero) PT PLN to PJB2.

$$
\text { inventory usage year }
$$

Inventory turn over $=----------------------------1$
average (inventory) 


$$
\begin{aligned}
& - \text { Year } 1996=\frac{68.952 .836}{(64.760 .965+121.861 .423) / 2}=0,74 \text { time } \\
& - \text { Year } 1997=\frac{64.189 .482}{(107.001 .414+64.760 .695) / 2}=0,75 \text { time }
\end{aligned}
$$

Because turnover is less than one, then the average PT PLN PJB2 warehouse inventory exceeds demand year. On certain types of material possible slow-moving due to emergency reasons or just in case, the procurement process is relatively long, the default engine spare parts at the time of construction and so on. Average age of inventory, which measures how long it takes for each inventory turnover.

average inventory $\mathrm{x} 365$

$$
\begin{aligned}
& \text { Average age of inventory }=-10 \\
& \text { Year } 1996=\frac{(64.760 .695+121.861 .423) / 2}{68.952 .836} \times 365=493,94 \text { day (494 day) } \\
& \text { Year } 1997=\frac{(107.001 .414+64.760 .495) / 2}{64.189 .482} \times 365=488,34 \text { day (489 day) }
\end{aligned}
$$

Although the amount of usage declined in 1997, but the average inventory is lower than the previous year, so that the deposition of funds PT PLN PJB2 on warehouse inventory shorter time than in 1996.

Solvency levels (Leverage)

These ratios measure the company's ability to restore all its financial obligations. Financial ratios are often used in analyzing the level of leverage, namely: Debt ratio, comparing the amount of debt with the rest of the company's assets.

$$
\begin{aligned}
\text { total debt } & \text { total assets } \\
\text { Debt ratio } & =- \text { Year } 1996=\frac{1.074 .944 .665}{6.204 .181 .875} \times 100 \%=17,33 \% \\
& - \text { Year } 1997=\frac{1.177 .118 .326}{6.194 .727 .201} \times 100 \%=19,00 \% .
\end{aligned}
$$

Guarantee assets of all financial obligations of PT PLN PJB2 quite high, due to the relatively small percentage. The increase in the percentage in 1997 is not very meaningful, and the company is still in a position very solvable. Debt equity ratio, shows a comparison between the long-term debt with its own capital.

$$
\text { long-term debt }
$$

$$
\begin{aligned}
& \text { Debt equity ratio }=-----------------------------------\times 100 \% \\
& \text { - Year } 1996=\frac{813 \cdot 900 \cdot 500}{5 \cdot 129 \cdot 237.210} \times 100 \%=15,85 \% \\
& \text { - Year } 1997=\frac{721.900 .172}{5.017 .608 .875} \times 100 \%=14,39 \%
\end{aligned}
$$

In 1997 the number of long-term debt is lower, so the percentage is down. The figure shows that the position of long-term debt is relatively very small compared to the model itself PT PLN PJB2.

Debt to total capitalization, shows how much the company's long-term capital financed by long term debt

$$
\begin{aligned}
& \begin{array}{l}
\text { Debt to total capitalization }=\frac{1 \text { long-term debt }}{\text { long-term debt }+ \text { capital }} \\
- \text { Year } 1996=\frac{813.091 .500}{813.091 .500+5.129 .237 .210} \times 100 \%=13,68 \%
\end{array} \\
& \text { - Year } 1997=\frac{721.900 .172}{721.900 .172+5.017 .608 .875} \times 100 \%=12,58 \%
\end{aligned}
$$

Contribution of long-term debt of PT PLN PJB2 to total capitalization is relatively very small, even in 1997 fell $1.10 \%$ over the previous year.

Time interest earned, to measure a company's ability to pay interest on the loan. 
operating profit + Depreciation

$$
\begin{aligned}
\text { Time interest earned } & =- \\
- \text { Year } 1996 & =\frac{363.039 .082+335.028 .603}{69.636 .562}=10,12 \text { time } \\
- \text { Year } 1997 & =\frac{174.514 .873+335.702 .208}{63.706 .440}=8,01 \text { time }
\end{aligned}
$$

Despite the advantages of PT PLN PJB2 down in 1997, but the ability to pay the interest is still quite large. Debt service coverage, measures the company's ability to pay interest and principal.

Operating profit + depreciation

Debt service coverage =-------------------------------

$$
\begin{aligned}
& - \text { Year } 1996=\frac{363.039 .082+335.028 .603}{69.636 .562+98.603 .467}=4,15 \text { time } \\
& - \text { Year } 1997=\frac{174.514 .873+335.702 .208}{63.706 .440+96.968 .685}=3,18 \text { time }
\end{aligned}
$$

PT PLN PJB2 profit decline in 1997 did not significantly affect the ability to pay interest and debt repayments.

\section{Profitability levels}

There are several measurements of the profitability of the company, each of which is associated with the measurement of assets, equity, and sales. Of measurement, enabling the ability to analyze the level of profit, economic profitability, measures the ability of the operation to restore the assets invested in the company.

operating profit

$$
\begin{aligned}
\text { Economic profitability } & =---\frac{\text { assets (average) }}{363.039 .082} \\
- \text { Year } 1996 & =\frac{174.514 .873}{(6.204 .181 .875+6.052 .654 .733) / 2} \times 100 \%=5,92 \% \\
- \text { Year } 1997 & =\frac{100 \%}{(6.194 .727 .201+6.204 .181 .875) / 2} \times 100 \%=2,82 \%
\end{aligned}
$$

1997 operating profit decline in the ability of PT PLN PJB2 investment returns. This is mainly due to higher operating costs as the impact of monetary shocks, where the natural gas fuel purchased with dollars (USD) from Pertamina. While the contribution of natural gas fuel costs account for about $72.44 \%$ of the total fuel costs in 1997.

Return on equity (ROE), which measures the level of benefits available to owners of the company either as holders of common stock and preferred shareholders.

$$
\begin{aligned}
\text { Return on equity }(\mathrm{ROE}) & =- \text { net profit } \\
- \text { Year } 1996 & =\frac{292.849 .237}{5.129 .237 .210} \times 100 \%=5,71 \% \\
- \text { Year } 1997 & =\frac{114.812 .307}{5.017 .608 .875} \times 100 \%=2,29 \%
\end{aligned}
$$

The ability to obtain a net profit of PT PLN PJB2 relatively very small, especially when compared with the general interest rate on average in the bank. Dropped dramatically in 1997 over the previous year, making it difficult to successfully go public when transfer pricing remains USD 82 per $\mathrm{kWh}$.

Return on investment (ROI), measures the overall ability of the company to generate profits to return the investments made in the company's assets.

$$
\begin{aligned}
& \text { Return on investment }(\mathrm{ROI})=\frac{\text { net profit }}{\text { assets (average) }} \\
& \quad-\text { Year } 1996=\frac{292.849 .237}{(6.204 .181 .875+6.052 .654 .733) / 2} \times 100 \%=4,78 \%
\end{aligned}
$$




$$
\text { - Year } 1997=\frac{114.812 .307}{(6.194 .727 .201+6.204 .181 .875) / 2} \times 100 \%=1,85 \%
$$

Investment capability generate profits in 1997 is relatively small, so that the average PT PLN PJB2 it took about 54 years to recover the investment, while the age of the assets is only about 25 years old.

Return on investment with Du Pont system, measures the ability of an investment to benefit by multiplying the net profit margin and total asset turnover.

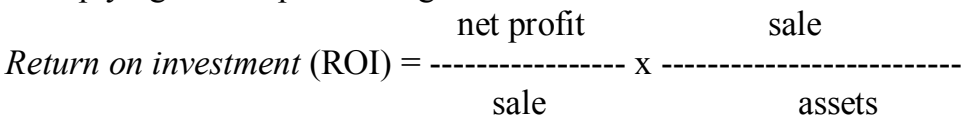

$$
\begin{aligned}
& \text { - Year } 1996=\frac{292 \cdot 849 \cdot 237}{2 \cdot 030 \cdot 215 \cdot 036} \times \frac{2 \cdot 030 \cdot 215 \cdot 036}{6 \cdot 204 \cdot 181 \cdot 875}=4,72 \% \\
& \text { - Year } 1997=\frac{114.812 .307}{2.051 .688 .380} \times \frac{2.051 .688 .380}{6.194 .727 .201}=1,85 \%
\end{aligned}
$$

Return on investment calculation results in the usual manner to item (c) above is similar to Du Pont formula, the result is the same even in 1997 is $1.85 \%$.

Operation margin, measuring the level of operating profit (pure profit) every dollar generated from the sale of the company

$$
\begin{aligned}
\text { Operating profit margin } & =- \text { operating profit } \\
\text { - Year } 1996 & =\frac{363.039 .082}{2.030 .215 .036} \times 100 \%=17,88 \% \\
- \text { Year } 1997 & =\frac{174.514 .873}{2.051 .688 .380} \times 100 \%=8,51 \%
\end{aligned}
$$

Operating profit generated by each sale of PT PLN PJB2 dollars, it is very small even in 1997 only reached $8.51 \%$, down sharply from the previous year.

Table 1. Overview of Income (Loss) of 1996 and 1997 PT PLN PJB2

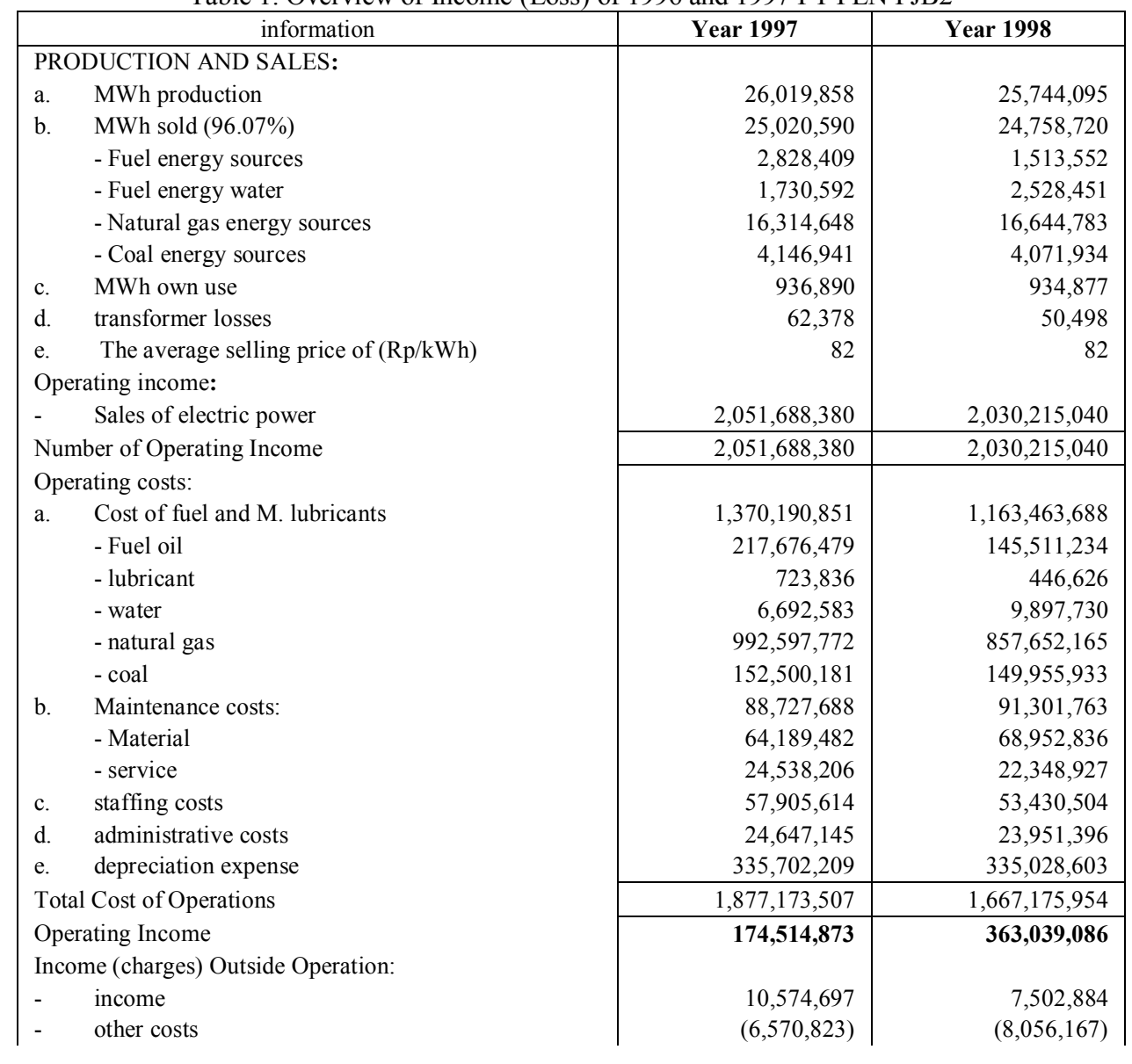




\begin{tabular}{|r|r|}
$(63,706,440)$ & $(69,636,562)$ \\
\hline$(59,702,566)$ & $(70,189,845)$ \\
\hline $\mathbf{1 1 4 , 8 1 2 , 3 0 7}$ & $\mathbf{2 9 2 , 8 4 9 , 2 4 1}$
\end{tabular}

Total Revenues (Costs) Outside Operations

Profit (Loss) Current Year

Sources: Annual Report of PT PLN PJB2 Calculation of 1996 and 1997

Table 2. Balance Sheet As of December 31, 1996 and 1997 PT. PLN PJB 2 (in thousands of dollars)

\begin{tabular}{|c|c|c|}
\hline 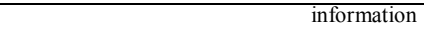 & 31 Des 1997 & 31 Des 1996 \\
\hline \multicolumn{3}{|l|}{ ASSETS } \\
\hline Fixed assets (gross) & $5,978,398,483$ & $5,841,545,983$ \\
\hline accumulated depreciation & $(756,714,452)$ & $(425,955,519)$ \\
\hline Fixed assets (net) & $5,221,684,031$ & $5,415,590,464$ \\
\hline Work in the implementation of & $29,224,203$ & $6,823,759$ \\
\hline other assets & $104,668,276$ & $97,653,294$ \\
\hline \multicolumn{3}{|l|}{ current assets: } \\
\hline - $\quad$ Cash and banks & $98,647,943$ & $86,035,445$ \\
\hline - $\quad$ claim & $575,478,100$ & $515,567,076$ \\
\hline - $\quad$ Fuel and maintenance materials & $107,001,414$ & $64,760,695$ \\
\hline - $\quad$ Other current assets & $58,023,234$ & $17,751,142$ \\
\hline Total current assets & $839,150,691$ & $684,114,358$ \\
\hline TOTAL ASSETS & $6,194,727,201$ & $6,204,181,875$ \\
\hline \multicolumn{3}{|l|}{$\begin{array}{l}\text { CAPITAL AND LIABILITIES } \\
\text { : equity }\end{array}$} \\
\hline - $\quad$ paid-in capital & $3,000,000,000$ & $3,000,000,000$ \\
\hline - $\quad$ Additional paid-in capital & $1,821,579,121$ & $1,821,579,121$ \\
\hline - $\quad$ Retained earnings & $196,029,754$ & $307,658,089$ \\
\hline Amount of own capital & $5,017,608,875$ & $5,129,237,210$ \\
\hline : Long-term liabilities & & \\
\hline - $\quad$ Long-term liabilities & $715,827,348$ & $813,091,500$ \\
\hline - $\quad$ Other long-term liabilities & $6,072,824$ & \\
\hline Number of long-term liabilities & $721,900,172$ & $813,091,500$ \\
\hline Short-term liabilities & $455,218,154$ & $261,853,165$ \\
\hline TOTAL CAPITAL AND LIABILITIES & $6,194,727,201$ & $6,204,181,875$ \\
\hline
\end{tabular}

Sources: Annual Report of PT PLN PJB2 Calculation of 1996 and 1997

\section{Analysis of Cost Structure and Rates}

PT PLN's operating cost structure PJB2 1997 shows the contribution of each component of these costs, namely fuel and lubricating oil $72.99 \%, 4.73 \%$ maintenance costs, personnel costs $3.08 \%, 1.31 \%$ other administrative costs and cost of depreciation of fixed assets $17.89 \%$.

Analysis of the connection between the structure and the cost of electricity sales tariff PT PLN PJB2 can use contribution margin approach and breakeven analysis. Of the analysis can be described levels of profitability and performance of PT PLN PJB2 especially in the development of cost-efficiency and power sales tariff policy. While the selling price per $\mathrm{kWh}$ of $\mathrm{Rp} 82$, so still a positive contribution margin was calculated as follows:

- Year $1996=\operatorname{Rp} 82-\operatorname{Rp~50,68=Rp~31,32.~}$

- $\quad$ Year $1997=\mathrm{Rp} 82-\mathrm{Rp} 58,31=\mathrm{Rp} 23,69$.

Differences in variable costs in 1996 and 1997 primarily due to (a) differences in the composition of the generators, (b) the monetary turmoil since July 1997 that impacted on the price of natural gas and the cost of spare parts for machinery maintenance and (c) the cost of fuel between machines -generating machines differ from one another either because of capacity and production volume.

Fuel per $\mathrm{kWh}$ according to the type of plant appropriate accounting data and reports produced by PT PLN PJB2 1996 and 1997, ie

- $\quad$ - Generation by Fuel

- $\quad$ - Generation with water

\begin{tabular}{cc} 
Year 1996(Rp) & Year 1997(Rp) \\
\cline { 2 - 2 } 96,14 & 76,96 \\
3,91 & 3,87 \\
51,53 & 60,84 \\
36,83 & 36,77
\end{tabular}

- $\quad$ - Generation with coal 
Cost difference indicates that the engine is generating the most inexpensive hydroelectric power (hydropower), following a steam power plant (CPP) of coal, gas power plants and steam (combined cycle) with fuel and combined cycle natural gas with fuel oil.

Breakeven analysis or break-even point, showing the conditions in which the company does not make a profit and a loss. Of accounting data and reports the amount of production can be calculated breakeven in 1996 and 1997 as follows:

$$
\begin{array}{cc}
\text { breakeven }= & \mathrm{TR}=\mathrm{TC} \\
& \mathrm{PQ}=\mathrm{FC}+\mathrm{VQ} \\
\mathrm{PQ}-\mathrm{VQ}=\mathrm{FC} \\
\mathrm{Q}(\mathrm{P}-\mathrm{V})=\mathrm{FC} \\
\mathrm{Q}=\frac{\mathrm{FC}}{(\mathrm{P}-\mathrm{V})}
\end{array}
$$

where $\mathrm{Q}$ sum $\mathrm{kWh}$ sales at the break-even point, fixed costs $\mathrm{FC}, \mathrm{P}$ and $\mathrm{V}$ price $\mathrm{kWh}$ variable costs per $\mathrm{kWh}$. Breakeven in 1996:

$$
\begin{array}{ll}
\mathrm{Q} & =\frac{(53.430 .504+23.951 .396+335.028 .603)}{(82-50,68)}=\frac{412.410 .503}{31,32} \\
\mathrm{Q} & =13.167 .641 \mathrm{MWH}
\end{array}
$$

Breakeven in 1997:

$$
\begin{aligned}
& \mathrm{Q}= \\
& \frac{(57.905 .614+24.647 .145+335.702 .209)}{(82-50,68)}=\frac{418.254 .968}{23,68}
\end{aligned}
$$

Sales of electric power in a period of two consecutive years, namely:

- Year $1996=24.758 .720 \mathrm{MWH}$

\begin{tabular}{|c|c|c|}
\hline information & Year 1996 & Year 1997 \\
\hline \multicolumn{3}{|l|}{ PRODUCTION AND SALES: } \\
\hline a. MWh production & $26,019,858$ & $25,744,095$ \\
\hline b. $\quad$ MWh sold $(96.07 \%)$ & $25,020,590$ & $24,758,720$ \\
\hline - Fuel energy sources & $2,828,409$ & $1,513,552$ \\
\hline - Water energy sources & $1,730,592$ & $2,528,451$ \\
\hline - Natural Gas energy sources & $16,314,648$ & $16,644,783$ \\
\hline - Coal energy sources & $4,146,941$ & $4,071,934$ \\
\hline MWh own use & 936,890 & 934,877 \\
\hline shrinkage transformer & 62,378 & 50,498 \\
\hline e. The average selling price ( $\mathrm{Rp} . / \mathrm{kWh})$ & 82 & 82 \\
\hline \multicolumn{3}{|l|}{ Operating income: } \\
\hline - $\quad$ Sales of electric power & 82 & 82 \\
\hline \multirow{2}{*}{$\begin{array}{l}\text { Number of Operating Income } \\
\text { Operating costs: }\end{array}$} & 80 & 82 \\
\hline & \\
\hline a. Cost of fuel and M. lubricants & 54.76 & 46.99 \\
\hline - Fuel oil & 76.96 & 96.14 \\
\hline - lubricant & 0.03 & 0.02 \\
\hline - water & 3.87 & 3.91 \\
\hline - natural gas & 60.84 & 51.53 \\
\hline - coal & 36.77 & 36.83 \\
\hline Maintenance costs: & 3.55 & 3.69 \\
\hline - Material & 2.57 & 2.78 \\
\hline
\end{tabular}

- $\quad$ Year $1997=25.020 .590 \mathrm{MWH}$

Breakeven in 1997 shifted the MWH larger amount than in 1996 because of the financial turmoil which resulted in the rising cost of natural gas fuel and engine maintenance cost of spare parts.

For two consecutive years PT PLN PJB2 production above the breakeven point, so there is no advantage because the excess price above variable costs are still able to cover all fixed costs. But in 1998, PT PLN PJB2 difficult to produce above the break-even when viewed in the action plan of the company (CBP) as follows: Breakeven in 1998:

$$
\mathrm{Q}=\frac{(58.314 .766+27.136 .525+442.340 .293)}{(82-69,22)}=\frac{527.791 .584}{12,78}
$$

$\mathrm{Q}=\quad 41.298 .246 \mathrm{MWH}$

Table 3. Earnings (Loss) unit kWh in 1996 and 1997 PT PLN PJB2 


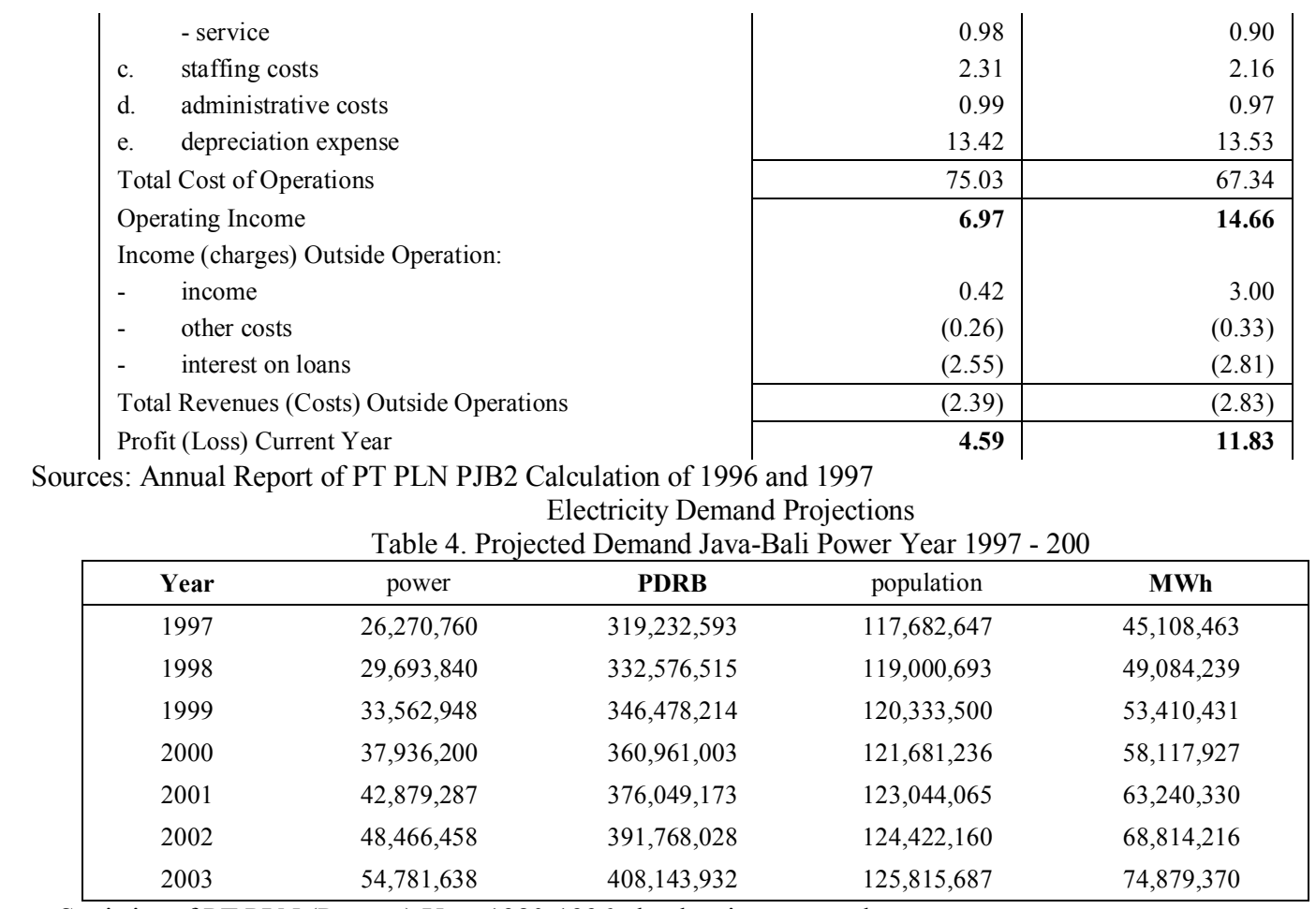

Source: Statistics of PT PLN (Persero) Year 1980-1996, the data is processed

\section{Sensitivity Analysis.}

Component of operating expenses in 1998 of PT PLN PJB2 converted to USD exchange rate at the beginning of the preparation conditions of the action plan of the company (U.S. $\$ 1=$ Rp 3,200), the maintenance cost of $\mathrm{Rp} 66,425,923,000$, - and the cost of natural gas fuel $\mathrm{Rp} 1,131,918,920.000$, -. Such costs totaled approximately $55.30 \%$ of the total operating costs in 1998 , and this composition will increase in line with the increase in the value of the dollar exchange rate.

Loss per $\mathrm{kWh}$ is above is not directly linear with the changes in the dollar exchange rate, because the only change to the cost of maintenance and fuel costs of natural gas. While there are many other factors affecting income such as rates, other operating income, other operating expenses, operating income and expenses beyond.

Return on equity (ROE) at various dollar exchange rate, will show how much electricity sales tariff should be treated PT PLN PJB2. Return on equity is recommended to go public is the range in the level of general interest or ROE refers to companies that have successfully gone public. As a reference according to the news Bisnis Indonesia on 11 and 18 March 1998 reported that ROE in 1996 and 1997 for PT Indosat, respectively $20.36 \%$ and $21.33 \%$, while the PT TELKOM is $16.95 \%$ and $11.95 \%$. In this study selected scenario ROE $15 \%$ and $20 \%$ to determine how much the fare should be required PT PLN PJB2 dollar exchange rate at the various possibilities, namely:

\begin{tabular}{|c|c|c|c|}
\hline & & $\underline{\mathrm{ROE} 15 \%}$ & ROE 20\% \\
\hline & Kurs USD ( $\$ 1=\operatorname{Rp} 3.200)$ & Rp 121,60 & Rp 138,49 \\
\hline & Kurs USD ( $\$ 1=\operatorname{Rp} 7.000)$ & Rp 181,69 & Rp 198,57 \\
\hline & Kurs USD ( $\$ 1=\operatorname{Rp} 8.000)$ & Rp 197,51 & Rp 214,39 \\
\hline & Kurs USD ( $\$ 1=\operatorname{Rp} 9.000)$ & Rp 213,32 & Rp 230,20 \\
\hline & Kurs USD $(\$ 1=\operatorname{Rp} 10.000)$ & Rp 229,14 & $\operatorname{Rp} 246,02$ \\
\hline
\end{tabular}

When the dollar exchange rate of Rp 8,000 , the electricity sales tariff PT PL (15.87\% increase in ROE $15 \%$ and $161.45 \%$ increase in ROE $20 \%$. If ROE is a benchmark as we have done PT Indosat and PT Telkom, PT PLN PJB2 difficult to go public, because of the tariff adjustment was not possible under current conditions. Chooses ROA $5 \%$ and $10 \%$, due to age or economic depreciation calculation based PT PLN PJB2, which on average ranged from 10 years to 20 years. And as a reference ROA in 1996 and 1997 were achieved PT Indosat, respectively $18.31 \%$ and $18.11 \%$, while the PT TELKOM reached $8.45 \%$ and $5.77 \%$. Rates are to be treated on the ROA of $5 \%$ and $10 \%$ at various dollar exchange rate, namely:

\begin{tabular}{|c|c|c|}
\hline & $\underline{\text { ROA } 5 \%}$ & $\underline{\mathrm{ROA}} 10 \%$ \\
\hline Kurs USD $(\$ 1=R p \quad 3.200)$ & Rp 100,64 & Rp 122,37 \\
\hline Kurs USD $(\$ 1=R p \quad 7.000)$ & Rp 160,74 & $\operatorname{Rp} 182,46$ \\
\hline Kurs USD $(\$ 1=\operatorname{Rp} \quad 8.000)$ & Rp 176,55 & Rp 198,28 \\
\hline Kurs USD $(\$ 1=\operatorname{Rp} 9.000)$ & Rp 192,37 & $\operatorname{Rp} 214,09$ \\
\hline Kurs USD $(\$ 1=\operatorname{Rp} 10.000)$ & $\operatorname{Rp} 208,18$ & Rp 229,91 \\
\hline
\end{tabular}


When the desired return on assets or investments for 10 years (ROA 10\%), then the exchange rate of U.S. $\$ 1=$ $\mathrm{Rp} 8,000$ should be charged a rate of $\$ 198.28$ per $\mathrm{kWh}$ or need an increase of about $141.80 \%$ from a rate of $\$$ 82 , - in effect now.

When connected between ROA and ROE, then the results can be compared as follows

\begin{tabular}{|c|c|c|}
\hline & $\underline{\text { ROE }(\%)}$ & ROA (\%) \\
\hline Laba Rp 989.326 juta & 15,00 & 9,83 \\
\hline Laba Rp 1.389 .046 juta & 20,00 & 13,38 \\
\hline Laba Rp 463.077 juta & 7,85 & 5,00 \\
\hline 977.407 juta & 15,24 & 10,00 \\
\hline
\end{tabular}

And so on the various possible rates of exchange prevailing when connected between ROA and ROE, which is smaller than ROA ROA.

Table 5. Projected Balance Sheet As of December 31, 1998 PT PLN PJB2 (in thousands of rupiah)

\begin{tabular}{|c|c|}
\hline information & 31 Des 1998 \\
\hline \multicolumn{2}{|l|}{ ASSETS } \\
\hline Fixed assets (gross) & $8,748,626,394$ \\
\hline accumulated depreciation & $(1,179,661,860)$ \\
\hline Fixed assets (net) & $7,568,964,534$ \\
\hline Work in the implementation of & $54,000,000$ \\
\hline other assets & $120,722,732$ \\
\hline Investments in subsidiaries & $24,800,000$ \\
\hline \multicolumn{2}{|l|}{ Current assets: } \\
\hline - Cash and banks & $109,480,209$ \\
\hline - claim & $346,158,176$ \\
\hline - $\quad$ Fuel and maintenance materials & $70,764,459$ \\
\hline - Other current assets & $39,904,043$ \\
\hline Total current assets & $566,306,887$ \\
\hline TOTAL ASSETS & $8,334,794,153$ \\
\hline \multicolumn{2}{|l|}{ CAPITAL AND LIABILITIES } \\
\hline \multicolumn{2}{|l|}{ Equity capital: } \\
\hline - paid-in capital & $3,000,000,000$ \\
\hline - $\quad$ Additional paid-in capital & $2,329,708,946$ \\
\hline - $\quad$ retained earnings & $106,476,154$ \\
\hline - $\quad$ Profit for the period & $(463,672,190)$ \\
\hline Amount of own capital & $4,972,512,910$ \\
\hline \multicolumn{2}{|l|}{ Long-term liabilities: } \\
\hline - Long-term liabilities: & $2,693,195,787$ \\
\hline - $\quad$ Other long-term liabilities & $6,017,986$ \\
\hline Number of long-term liabilities & $2,699,213,773$ \\
\hline Short-term liabilities & $663,067,470$ \\
\hline TOTAL CAPITAL AND LIABILITIES & $8,334,794,153$ \\
\hline
\end{tabular}

Sources: Company Budget Plan (CBP) 1998 PT PLN PJB2

\section{IV . Conclusion}

Data analysis based on the description above, then the following can be inferred, namely:

Financial performance, PT PLN PJB2 reflect an adequate level of liquidity with current ratio above $200 \%$. In terms of activity, it is relatively small asset turnover, receivables turnover less current so as to achieve approximately three months arrears of sales, warehouse inventory piling or exceed the needs of an average of one year. Performance solvency or leverage is strong enough that the debt equity ratio is only about $15 \%$, which means the lender is guaranteed . Very low level of profitability, especially in 1997, which is only about $2.29 \%$ ROE and $1.85 \%$ ROA. This complicates the position of PT PLN PJB2 to go public, because it is still far from the expected profitability levels of ROE around $15 \%$ per year .

Factors that influence, the poor performance of PT PLN PJB2 profitability mainly due to the limited market share, cost structure and sale of electricity tariff . Positive contribution margin in 1996 and 1997 , showed that each increase market share or sales will increase profits . Market share held by PT PLN PJB2 1997 has surpassed the point of break -even point, which means more and increase profit increase sales . The cost structure of generation centers showed that hydropower is the cheapest, followed by power plant coal, natural gas combined cycle and combined cycle oil. While electricity sales tariff has been determined since the establishment of PT PLN PJB2, apparently has never been reviewed, although PT PLN ( Persero ) has made several automatic tariff adjustment ( ETAM ) to consumers . 
Projected demand, power Java - Bali system increased by about $66 \%$ until the end of 2003 , and in the same period the market share of PT PLN PJB2 increased by approximately $44.37 \%$. To reach the point of break even point in 1998, the share of PT PLN PJB2 demand must be increased approximately $65.06 \%$ if the electricity sales tariff of Rp 82 per $\mathrm{kWh}$ is not adjusted .

Monetary shocks, which occurred since July 1997 , led to the financial performance declined compared to 1996. And the various possibilities dollar exchange rate prevailing in 1998, showed that the PT PLN PJB2 will experience losses . Electricity sales tariff under conditions break even point at about $\mathrm{Rp} 101.58$ per $\mathrm{kWh}$ in the USD exchange rate of Rp 3,200 ( initial condition of planning ), and Rp 177.49 per $\mathrm{kWh}$ in the USD exchange rate of Rp 8,000. When the desired level of ROE is $15 \%$, the electricity sales tariff of Rp 197.51 per kWh in the USD exchange rate of Rp 8,000 .

\section{Suggestion}

From the analysis above, it can be concluded as follows: To improve the profitability of PT PLN PJB2 advised to review the sale of electricity tariff charged to PT PLN P3B. With a high ROE allow successful public offering and the results back to PT PLN (Persero) as a shareholder to meet the needs of investment funds.

Generating capacity owned by PT PLN PJB2 only reached about $60 \%$ capacity factor and are still more likely to increase sales. It is recommended for optimal capacity utilization in order to increase the profitability of the company. Operation of the centers of power to be made according to priority level operating cost efficiency, and should take into account the constraints of operating in order to avoid excessive unemployment capacities.

Wisdom of the discount rate on excess market share given by PLN P3B as an alternative to improve the utilization of excess capacity. Recommended for adoption by the discount rate to a greater extent than the variable cost per $\mathrm{kWh}$ or contribution margin is positive, because the company is still profitable.

To anticipate things that may have an adverse effect on the financial performance of PT PLN PJB2, it is suggested that the financial projections with various scenarios relevant to benchmark the financial wisdom particularly with respect to rates, capital structure, capital expenditure and operating cost structure

\section{Bibliography}

[1]. Agus Maulana ., 1992. Management Control Systems . Jakarta : Publisher Banipura Literacy.

[2]. Agus Sartono, R. , 1994. Financial Management - Theory and Applications . London: Publisher BPFE .

[3]. Amarullah. 1984. Analisis Permintaan Tenaga Listrik Konsumen Sektor Rumah Tangga. Jakarta

[4]. Aminullah Assagaf. 1994.Analisis Struktur Permintaan Tenaga Listrik pada PLN Wilayah VIII, Sulawesi Selatan Tenggara. Ujung Pandang.

[5]. Bambang Riyanto ., 1984. Fundamentals of corporate expenditures . Yogyakarta : Gajah Mada Publisher Publisher Foundation Board .

[6]. Burhan, N. , 1994. Strategic Planning . Jakarta : PT . Library Binaman Pressindo .

[7]. Charles P. Jones ., 1996. Investment - Analysis and Management . New York : John Wiley \& Sons , Inc.

[8]. Clive Gray ., 1993. Introduction to Project Evaluation. Jakarta : Gramedia Pustaka Utama .

[9]. Dominick Salvatore ., 1984. Microeconomics theory . Jakarta : publisher grants .

[10]. Eugene F. Brigham and Louis C.G., 1993. Intermediate Financial Management .

[11]. London : Harcourt Brace \& Company - International Edition

[12]. Evan J. Douglas. , 1992. Managerial Economic - Analysis and Strategy. New Jersey : Prentice Hall International Edition Englewood Cliffs .

[13]. Fred Weston, J and Eugene F. Brigham ., 1994. Basics of Financial Management. Jakarta : publisher grants .

[14]. Gerald I.W , Aswin Paul C.S and Dov Fried ., 1994. The Analysis and Use of Financial Statements . New York : John Wiley \& Sons , Inc.

[15]. John E. Hanke and Arthur G. Reitsch ., 1995. Business Forecasting . New Jersey : Prentice Hall International Edition - Englewood Cliffs .

[16]. Lincoln Arsyad ., 1987. Business Forecasting . London: Institute of Economic Faculty Publisher .

[17]. . 1993. Managerial Economics - Applied Microeconomics for Business Management . London: Publisher BPFE .

[18]. Lukman Shamsuddin ., 1994. Corporate Financial Management . Jakarta : PT Publisher . King Grafindo Persada .

[19]. Michael L. Tyrant ., 1991. The Vest Pocket Guide to Business Ratios . New Jersey : Prentice Hall International Edition - Englewood Cliffs .

[20]. Monasinghe Monang. 1979. Study of Electricity Demand Brazil. Cascavel City.

[21]. Napa J. Awat and Muljadi PS ., 1989. Corporate decisions - Theory and Empirical Test Result . London: Publisher Liberty .

[22]. Nazir , M. 1983. Research Methods . Jakarta : Publisher Ghalia Indonesia .

[23]. Pearce and Robinson ., 1997. Strategic Management . Jakarta : Publisher Binapura Literacy.

[24]. Robert C. Higgins ., 1996. Analysis of Financial Management . Jakarta : Publisher Indira .

[25]. Russel and Richard. 1982. Electricity Demand Studies for Bangladesh Power. Bangladesh.

[26]. Soekartawi ., 1994. Economic Theory of Production . Jakarta : PT Raja Grafindo Publisher Persada

[27]. Suad Hasnan and Emmy Pujiastuti ., 1994. Project Feasibility Study . Yogyakarta : Publisher UPP - AMP - YKPN

[28]. Sudarsono . 1983. Introduction to Microeconomics . Jakarta : Publisher LP3ES - University of Indonesia .

[29]. Sudrajat, BC ., 1984. Beginners to know Econometrics . Bandung : Publisher Ermico .

[30]. Sukanto Reksohadiprojo and Hani Handoko . 1982. Company organization - Structure Theory and Behavior . London: Publisher BPFE.

[31]. Soelistiyo . 1982. Introduction to Econometrics . London: The Publishers Faculty of Economics, University of Gajah Mada .

[32]. Supriyanto , Y., 1994. Corporate Budget - Planning and Control . London: The Publishers of Economics - YKPN .

[33]. Thomas WF. 1976. Electricity Demand in the United State of Amecrica. New York, USA.

[34]. Zuhal. 1985. Analisis Permintaan Tenaga Listrik Sektor Ruhal. 1985. Analisis Permintaan Tenaga Listrik Sektor Rumah Tangga, Sektor Komersil dan Sektor Pemerintah di Jawa. Jakarta 
[35]. . 1998. Advance Controls Budgeting and Profit Planning . Surabaya: Asia Pacific Institute for Management Development. Surabaya Stock Exchange.

[36]. . 1997. PT PLN PJB2 Financial Statements As of December 31, 1996 and 1995 . Surabaya.

[37]. _ . 1997. Extension and Capital Markets Venture Capital . Surabaya: Surabaya Stock Exchange .

[38]. _ 1996. Work Plan and Budget 1997. Surabaya : PLN PJB2 .

[39]. 1997. Work Plan and Budget 1998. Surabaya : PLN PJB2 . 